Intecoms: Journal of Information Technology and Computer Science

Volume 1 Nomor 2, Desember 2018

e-ISSN : 2614-1574

p-ISSN : 2621-3249

DOI : https://doi.org/10.31539/intecoms.v1i2.293

\title{
PENERAPAN SISTEM INFORMASI PERPUSTAKAAN PADA SMA NEGERI 2 MUARA BUNGO MENGGUNAKAN BAHASA PEMROGRAMAN JAVA DAN MARIADB
}

\section{IMPLEMENTATION OF LIBRARY INFORMATION SYSTEM IN SMA NEGERI 2 MUARA BUNGO USING JAVA AND MARIADB}

\author{
Yeviki Maisyah Putra \\ Universitas Putra Indonesia YPTK Padang \\ yeviki.maisyahputra@upiyptk.ac.id
}

\begin{abstract}
Computers are an electronic device that is not strange to every human being because it serves as a tool in all things. The computer has an application program capable of processing various types of data quickly, precisely and accurately. Therefore, many agencies that use computer services as a tool that can help in the activities of the company. Based on the research that has been done in the Library of SMA Negeri 2 Muara Bungo by using field research methods, libraries and laboratories, it is known that the system used in borrowing and returning books is still done manually and simply. With the design of Library information systems supported by Java programming language will provide better solutions to the problems encountered. The level of error in doing the calculations can be minimized, the information produced more accurately and the data can be stored safely.
\end{abstract}

Keywords : Library, Java, MariaDB, Library Information System

\begin{abstract}
ABSTRAK
Komputer merupakan suatu alat elektronik yang tidak asing bagi setiap manusia karena dijadikan sebagai alat bantu dalam segala hal. Komputer mempunyai program aplikasi yang mampu mengolah berbagai jenis data dengan cepat, tepat dan akurat. Oleh karena itu, banyak instansi-instansi yang menggunakan jasa komputer sebagai alat yang dapat membantu dalam aktifitas perusahaannya. Berdasarkan penelitian yang telah dilakukan pada Perpustakaan SMA Negeri 2 Muara Bungo dengan menggunkan metode penelitian lapangan, pustaka dan laboratorium, maka diketahui bahwa system yang digunakan dalam peminjaman dan pengembalian buku masih dilakukan secara manual dan sederhana. Dengan perancangan system informasi Perpustakaan yang didukung bahasa pemrograman Java akan memberikan solusi yang lebih baik terhadap masalah-masalah yang dihadapi. Tingkat kesalahan dalam melakukan perhitungan dapat diperkecil, informasi yang dihasilkan lebih akurat serta data-data dapat disimpan dengan aman.
\end{abstract}

Kata Kunci: Perpustakaan, Java, MariaDB, Sistem Informasi Perpustakaan 


\section{PENDAHULUAN}

Pesatnya perkembangan ilmu pengetahuan yang berkembang, maka semakin modern pula suatu alat-alat yang diciptakan manusia dalam menangani informasi yang sedang berjalan di segala bidang. Sehubungan dengan meningkatnya teknologi maka diciptakan suatu alat elektronika yang dapat diandalkan dalam pengolahan data dan informasi yang disebut komputer.

Perpustakaan sebagaimana yang ada dan berkembang sekarang telah dipergunakan sebagai salah satu pusat informasi, sumber ilmu pengetahuan, penelitian, rekreasi, pelestarian khasanah budaya bangsa, serta memberikan berbagai layanan jasa lainnya. Hal tersebut telah ada sejak dulu dan terus berproses secara alamiah menunjuk kepada suatu kondisi dan tingkat perbaikan yang signifikan meskipun belum memuaskan semua pihak. Sudah banyak penelitian tentang perancangan sistem perpustakaan baik itu berbasis web(Novia dkk, 2013, Firdaus dkk, 2015, Rahayu, 2016), mobile (Pradani dkk, 2013), android (Qamaruzzaman \& Haris, 2016), desktop (Sahab \& Pradnya D, 2015).

Perpustakaan adalah sebuah ruang dimana di dalamnya terdapat banyak buku yang disusun berdasarkan sistem tertentu untuk digunakan sebagai media dalam mencari ilmu dan wawasan bagi semua orang. Dengan semakin berkembangnya kegiatan dan inventaris suatu buku pada sebuah perpustakaan serta semakin bertambahnya anggota, maka diperlukan suatu sistem informasi yang dapat menampung semua informasi mengenai data-data tersebut secara cepat.

Penggunaan komputer pada sebuah perpustakaan sekolah diantaranya dapat digunakan untuk memproses data peminjaman dan pengembalian buku menjadi suatu laporan yang diinginkan oleh si pemakai. Namun karena data-data tersebut sangat banyak dan masih lemahnya kemampuan sistem yang lama dalam mengolah data, mengakibatkan tidak jarang terjadi kesalahan data sehingga proses pengolahan data sering direvisi kembali. Hal seperti ini sering mengakibatkan keterlambatan pelaporan data dan memerlukan waktu yang relatif lama.

Hal seperti ini dapat dijumpai pada perpustakaan SMA Negeri 2 Muara Bungo yang mana penggunaan sistem yang lama masih terdapat kelemahannya. Mengoptimalkan penggunaan komputer yang ada untuk memperoleh informasi yang lebih cepat, tepat dan akurat.

\section{METODE PENELITIAN JAVA}

Pada awalnya, java ditujukan untuk pemprograman device kecil berupa chip. Karena suatu hal. Perkembangannya menjadi terancam. Karena fitur-fitur java cocok dengan pengembangan internet, maka java diarahkan untuk pemrograman web. Pada perkembangannya, java telah dikembangkan menjadi sebuah bahasa universal yang mendukung pemrograman desktop.

Penamaan java terinspirasi ketika anggota tim sedang minum kopi di sebuah kedai. Salah seorang dari mereka bercanda tntang kopi dan teringat pada pulau jawa. Akhirnya, mereka sepakat untuk menamakan bahasa java dengan logo secangkir kopi panas.

Java telah mengalami perkembangan yang sangat pesat. Saat ini, java telah sampai versi ke-6. Paket Java JDK-6u6 mencakup SDK dan JRE. SDK digunakan untuk mengompilasi program java sedangkan JRE digunakan 
untuk mengoperasikan java bytecode (Jurnal Komputer, 2014).

\section{MariaDB}

MySQL adalah DBMS yang populer dan banyak digunakan oleh programmer. Dulunya MySQL adalah salah satu product dari Sun MicroSystem dan dikembangkan oleh komunitas.Akan tetapi sejak Sun MicroSystem diakuisisi oleh Oracle, beberapa produk dari Sun MicroSystem ada beberapa yang menjadi berbayar. Oleh karena itu pendiri dan pengembang MySQL membuat forking dari MySQL yaitu MariaDB. MariaDB adalah DBMS hasil forking dari DBMSMySQL. Jadi syntax query yang digunakan hampir sama.

MariaDB menerapkan lisensi bebas GNU/GPL. Nama MariaDB diturunkan dari nama putri ketiga Michael "Monty" Widenius, pendiri Monty Program dan MySQL. MariaDB memiliki banyak fitur yang sejak lama telah dipelihara komunitas sehingga menurut Monty seharusnya sangat stabil.

MariaDB telah mengganti InnoDB dengan XtraDB yang juga telah mendapat perbaikan dari Google dan Percona.XtraDB diklaim secara signifikan bisa jalan lebih cepat dibandingkan InnoDB, disamping ia juga bisa digunakan tanpa perlu memasang Plugin seperti halnya pada MySQL.

MariaDB meningkatkan portofolionya dengan fitur "synchronous Multi Master Replication".Untuk itu, pengembang MariaDB telah mengimplementasikan teknologi "Galera Cluster" yang dikembangkan oleh Codership dan ditanamkan langsung di sistem pengelolaan basis data MariaDB.Solusi ini memungkinkan replikasi terselaraskan (synchronous replication) dengan topologi Multi Master.

\section{Aliran Sistem Informasi (ASI)}

Aliran sistem informasi (ASI) merupakan bagan aliran yang menunjukkan arus data dari laporan dan formulir secara keseluruhan. ASI sangat berguna untuk mengetahui permasalahan yang ada pada suatu sistem. Jika sistem informasi yang digunakan suatu perusahaan tidak layak lagi dipakai, maka perlu adanya perubahan dalam pengolahan data sehingga menghasilkan sistem informasi yang cepat dan akurat serta menghasilkan suatu keputusan yang lebih baik.

\section{HASIL DAN PEMBAHASAN Analisa Sistem}

Tahap Analisa sistem dapat didefenisikan sebagai penguraian dari suatu sistem informasi yang utuh ke dalam bagian-bagian komponennya dengan maksud untuk mengidentifikasikan dan mengevaluasi permasalahan, kesempatan, hambatan yang terjadi dan kebutuhan yang diharapkan sehingga dapat diusulkan perbaikan-perbaikannya.

Pada Perpustakaan SMA NEGERI 2 MUARA BUNGO semua proses masih bekerja secara manual dimana pada proses pencatatan dan penyimpanan data masih menggunakan Buku Catatan dan Microsoft office excel sedangkan data-data yang disimpan tidak menggunakan database sehingga keamanan data tidak terjamin. Tujuan dari analisa sistem adalah untuk mengoptimalkan kerja dari sistem lama, sehingga kelemahan-kelemahan yang ada selama ini dapat teratasi. 
PERANCANGAN SISTEM

\section{Aliran Sistem Lama}

Aliran Sistem Lama (ASI) Lama merupakan gambaran sistem lama yang dipakai oleh Perpustakaan SMA Negeri 2 Muara Bungo, Contoh Aliran Sistem Lama pada Perpustakaan SMA Negeri 2 Muara Bungo dapat dilihat pada gambar

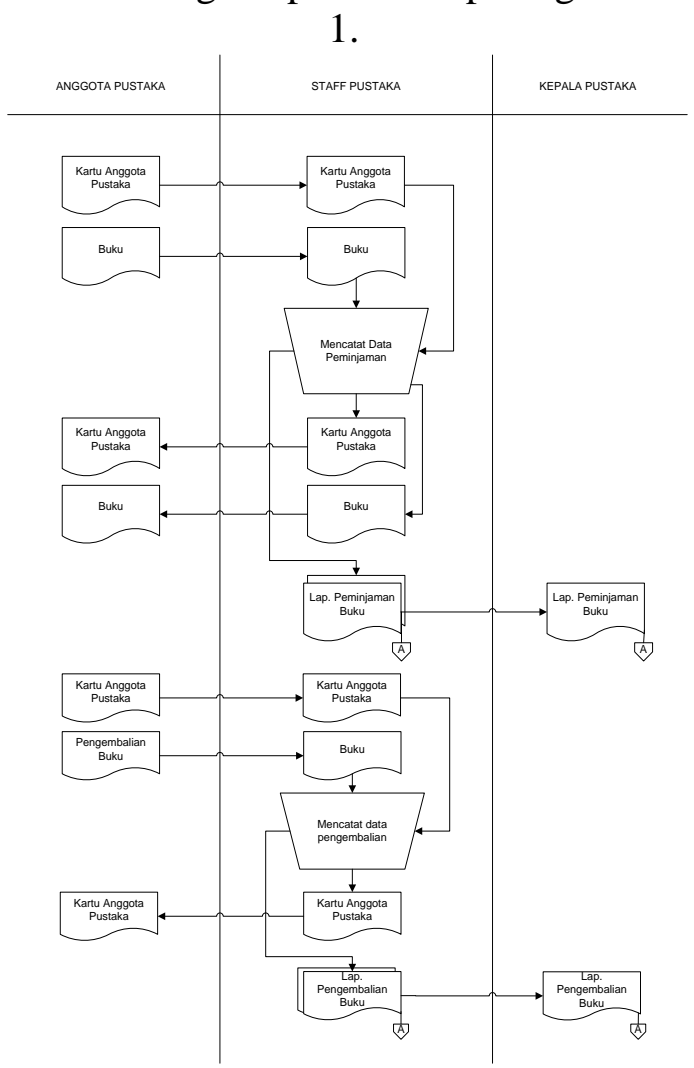

Gambar. 1 Aliran Sistem Lama

\section{Aliran Sistem Informasi Baru (ASI)}

Dalam merancang sistem yang baru sebaiknya perlu juga merancang aliran sistem yang baru yang dapat menutupi kelemahan dari aliran sistem yang lama misalnya, masih lambatnya dalam pembuatan laporan yang akan diserahkan kepada kepala pustaka dan kelemahan lain diantaranya data yang disimpan masih menggunakan arsiparsip. Dengan sendirinya hal ini juga akan memperlambat proses pelayanan peminjaman di Perpustakaan SMA Negeri 2 Muara Bungo itu sendiri.
Untuk itu peneliti berusaha mengusulkan dan sekaligus merancang suatu sistem yang baru tanpa mengabaikan sistem yang lama. Adapun aliran sistem yang baru adalah proses pembuatan laporannya mengunakan sistem komputerisasi serta laporannya disimpan dalam bentuk file agar mudah di akses dengan cepat bila diperlukan. Untuk lebih jelasnya aliran sistem yang baru pada Perpustakaan SMA Negeri 2

Muara Bungo dapat dilihat pada gambar 2.

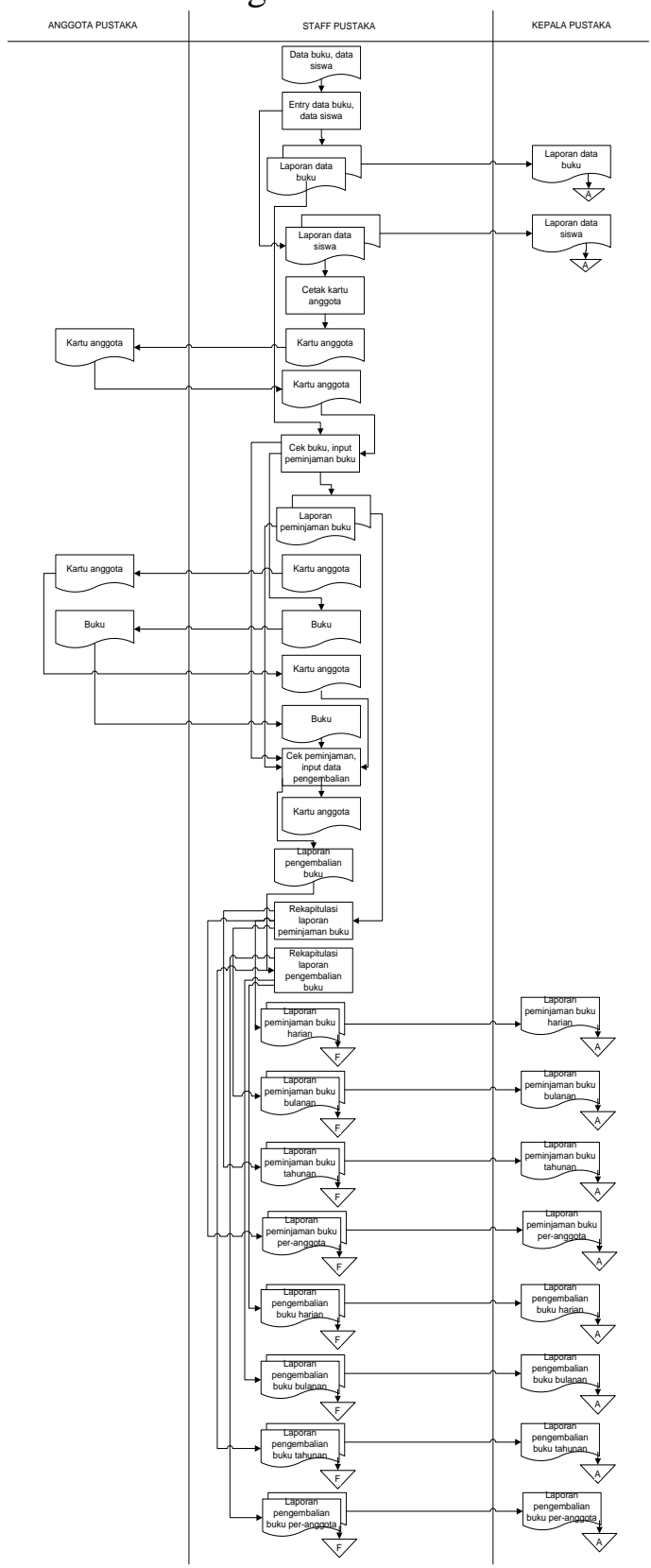

Gambar. 2 Aliran Sistem Baru(ASI) 


\section{Context Diagram}

Context Diagram adalah gambaran umum tentang suatu sistem yang terdapat didalam suatu organisasi yang memperlihatkan batasan (boundary) sistem, dan informasi secara umum mengalir diantara entity dan sistem. Context diagram ini merupakan alat bantu yang digunakan dalam menganalisa sistem yang akan dikembangkan.

Pada Context Diagram sistem informasi pada Perpustakaan SMA Negeri 2 Muara Bungo terdiri dari 3 entity, dimana entity-entity ini saling berinteraksi dengan baik dengan entity lain maupun dengan sistem. Untuk lebih jelasnya dapat dilihat pada gambar 3 .

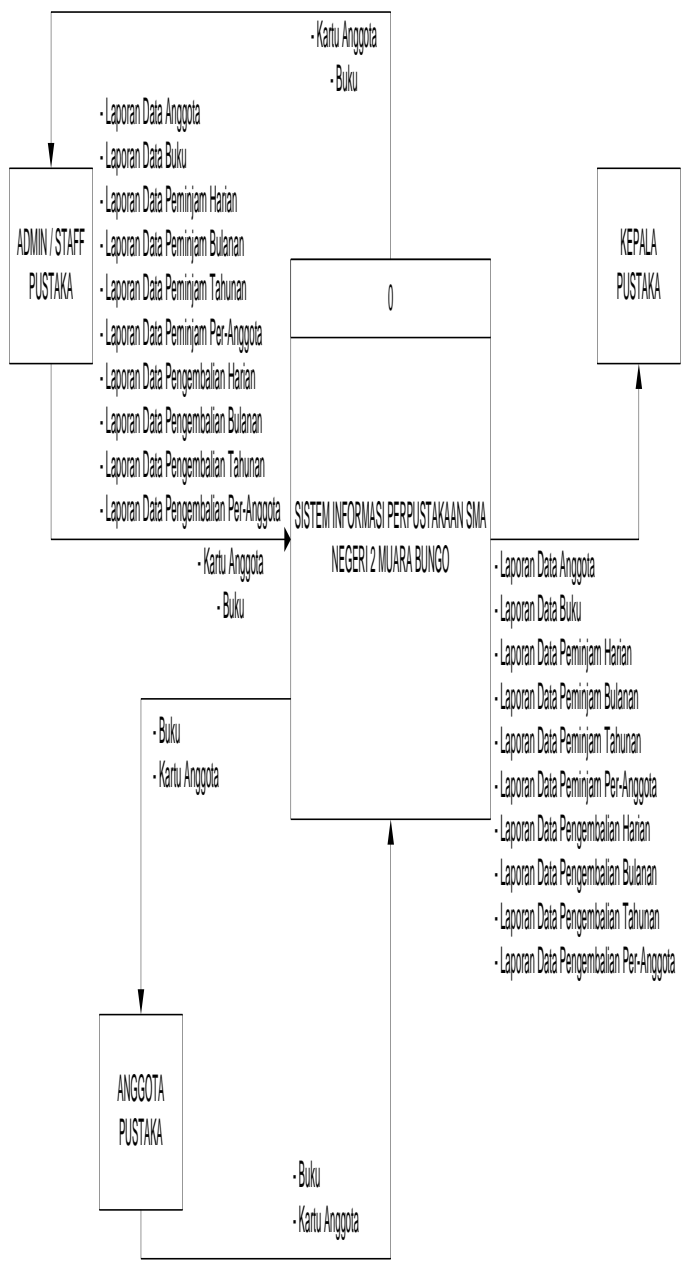

Gambar. 3 Context Diagram

\section{Data Flow Diagram (DFD) Level 0}

Data Flow Diagaram lever 0 berdasarkan pengembangan dari context diagram dimana dalam proses Data Flow Diagaram lever 0 tersebut diterangkan bagaimana laporan-laporan yang dihasilkan didapatkan dari berbagai macam proses, dimana proses tersebut saling berkaitan antara satu dengan lainnya. Untuk lebih jelas dapat dilihat pada gambar 4 .

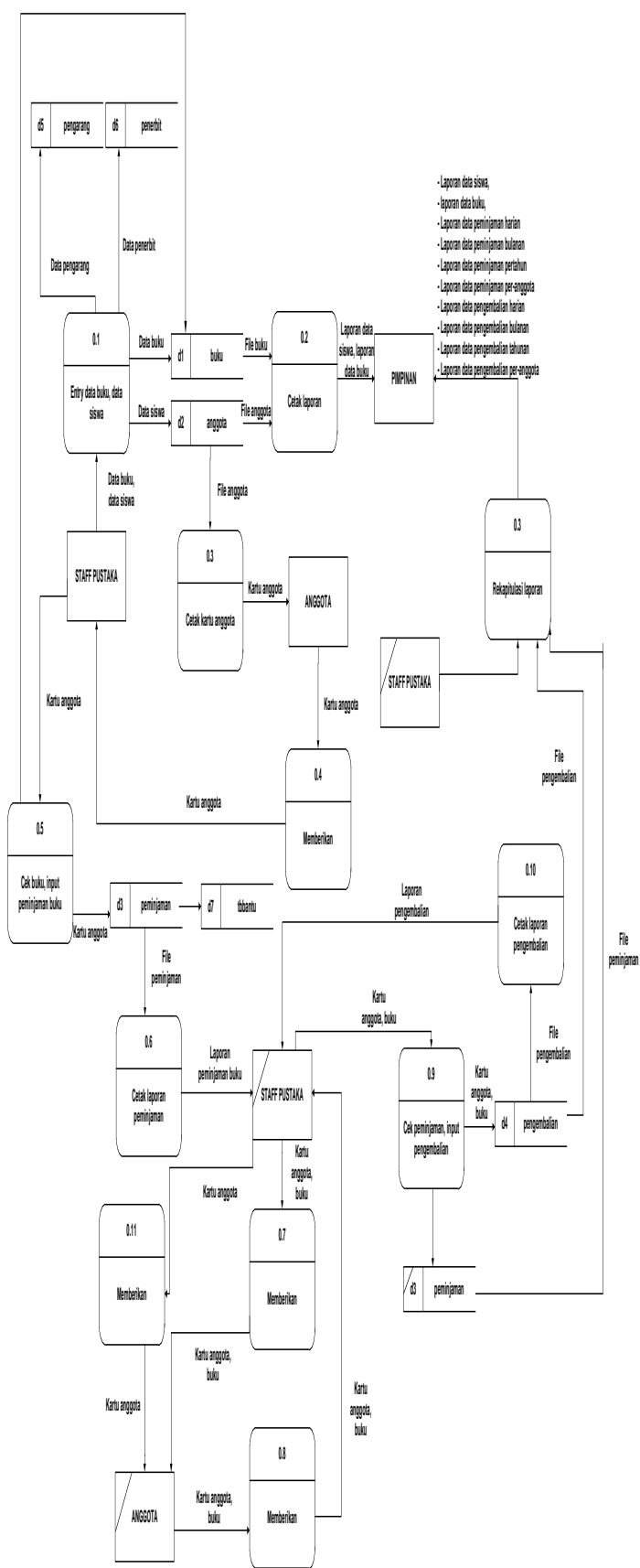

Gambar. 4 DFD Level 0 
Entity Relationship Diagram (ERD)

Entity Relationship Diagram adalah suatu model jaringan kerja yang menguraikan susunan data yang distore dari suatu sistem secara abstrak. Entity Relationship Diagram menunjukan hubungan antara entity di dalam sistem. Entity adalah orang, tempat benda yang memiliki nama yang umum, definisi yang umum suatu kepemilikan yang umum. Sebuah hubungan menunjukan bagaimana sebuah entity tersebut berinteraksi dan bekerjasama. Entity Relationship Diagram ini dapat dilihat pada gambar 5 berikut :

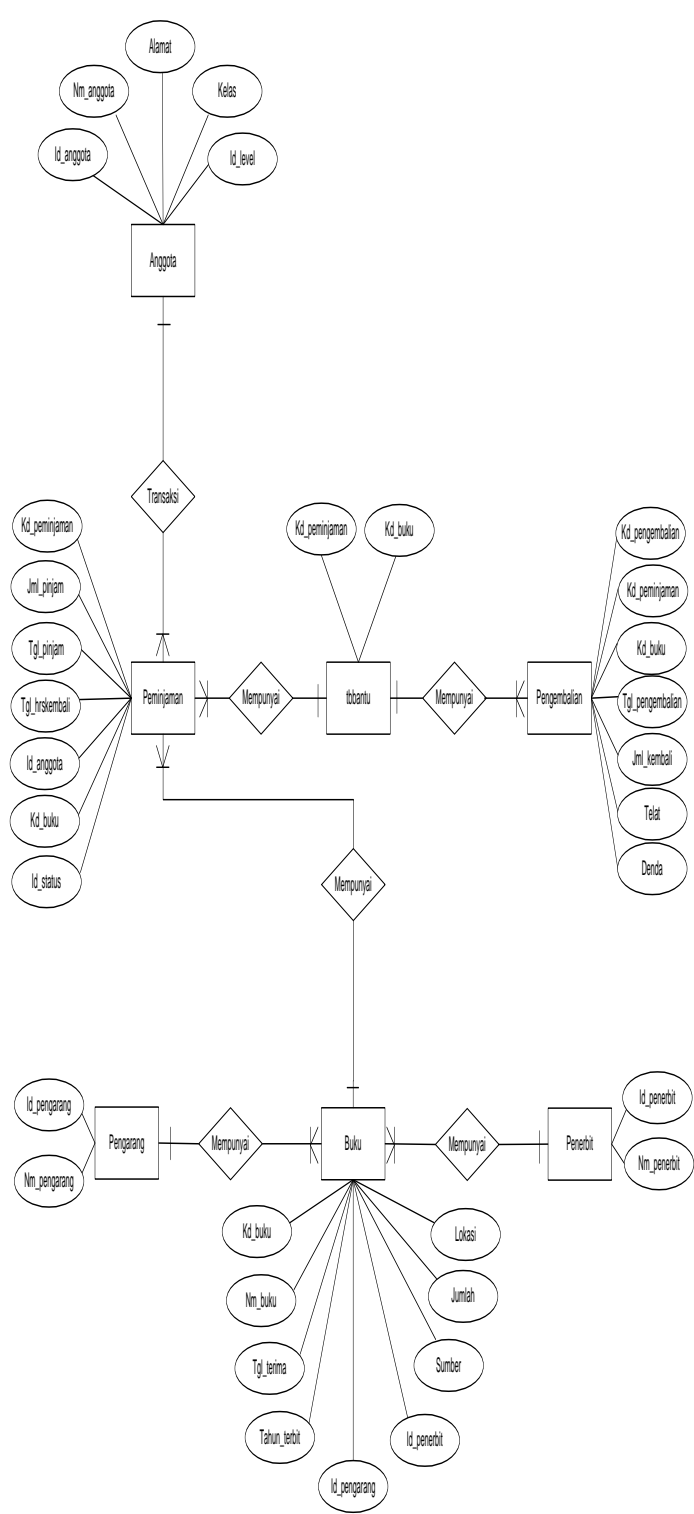

Gambar. 5 ERD

\section{Struktur Program}

Disain Struktur Program merupakan suatu desain yang menggambarkan hubungan antara suatu modul program dengan program yang lain. Disain struktur dari program yang dapat dilihat pada gambar 6 berikut :

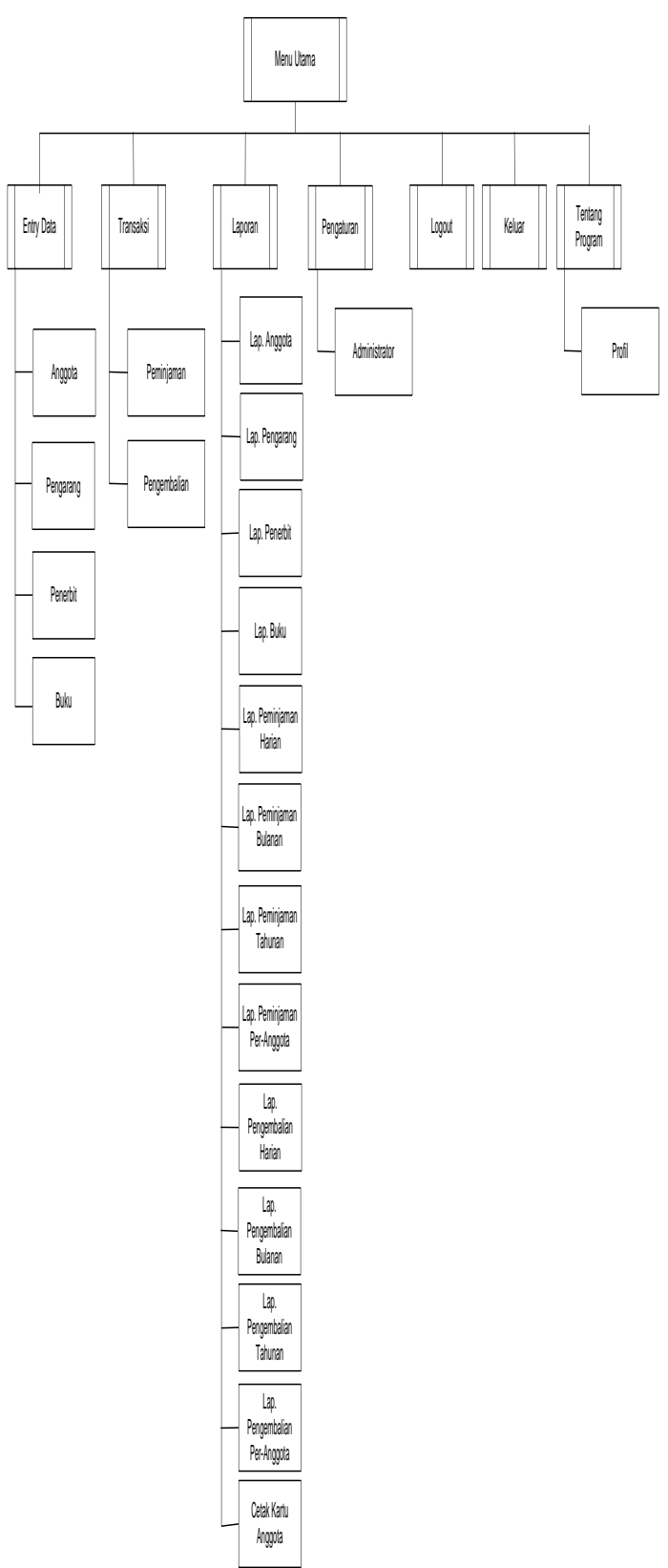

Gambar. 6 Struktur Program 


\section{Impelementasi Sistem}

Tampilan Awal

Tampilan awal pustaka menampilkan menu pilihan dan juga memiliki sub menu tersendiri. Tampilan program dari tampilan awal pada gambar 7. berikutini:

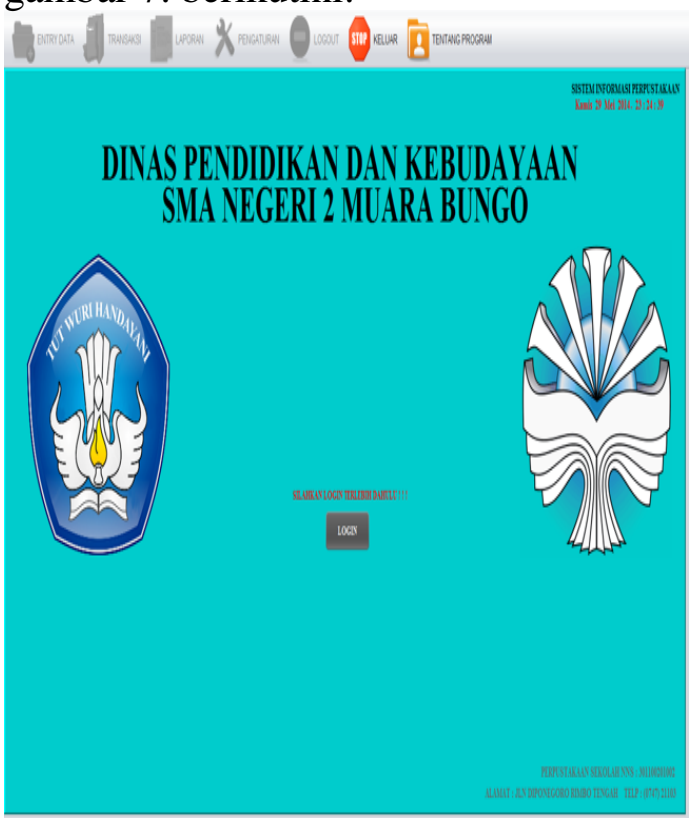

Gambar. 7 Tampilan Awal

\section{Tampilan Login}

Tampilan Login berfungsi untuk masuk kedalam menu utama. Tampilan program dari Tampilan Login pada gambar 8 . berikutini:

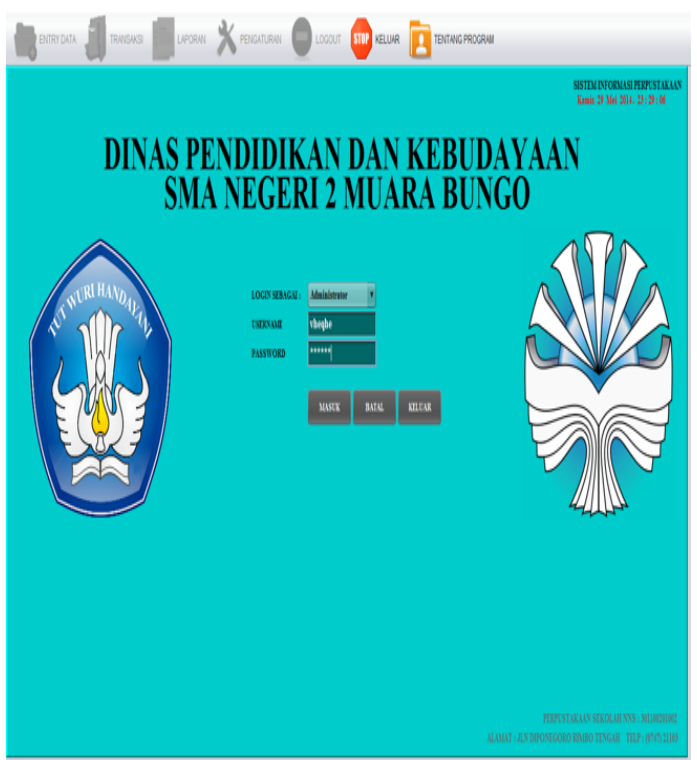

Gambar. 8 Tampilan Login

\section{Tampilan Menu}

Tampilan mensu setelah logindan masuk kedalam menu utama. Tampilan program dari Tampilan Menu pada gambar 9 berikutini:

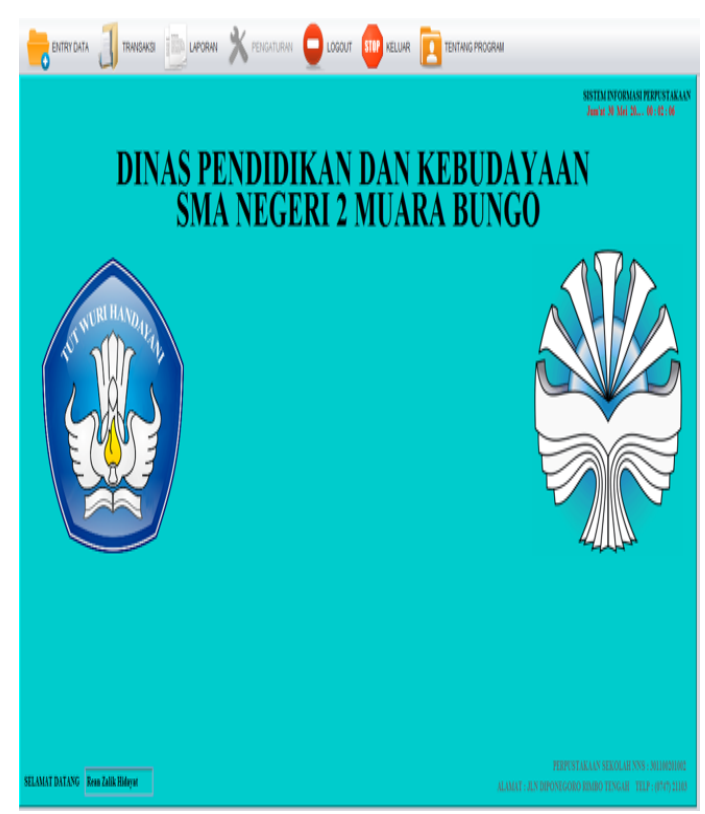

Gambar 9. Tampilan Menu

\section{Tampilan Input Anggota}

Tampilan Input Anggota berfungsi untuk menginputkan data anggota. Tampilan program dari Tampilan Input Anggota dapat dilihat pada gambar 10. berikut:

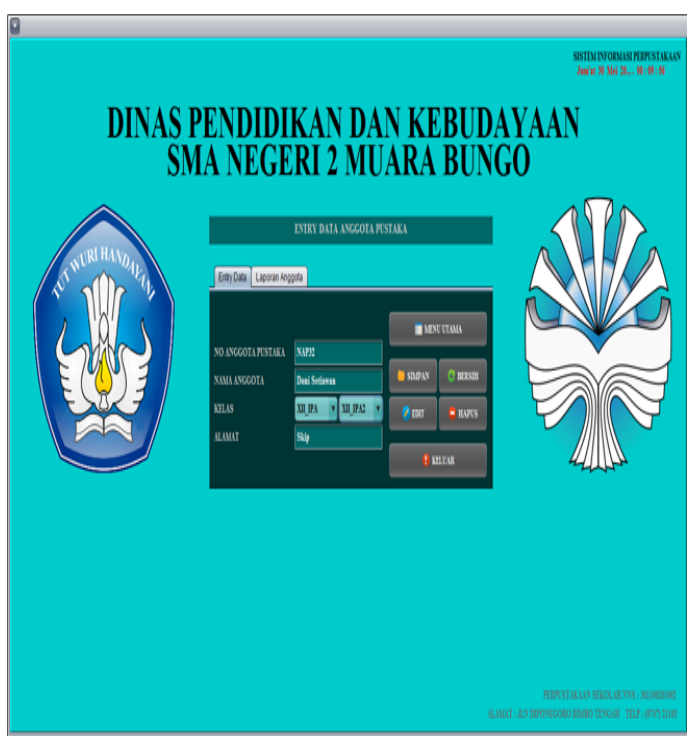

Gambar. 10 Tampilan Input Anggota 


\section{Tampilan Input Penerbit}

Tampilan Input Penerbit berfungsi untuk menginputkan data penerbit. Tampilan program dari Tampilan Input Penerbit dapat dilihat pada gambar 11. berikut:

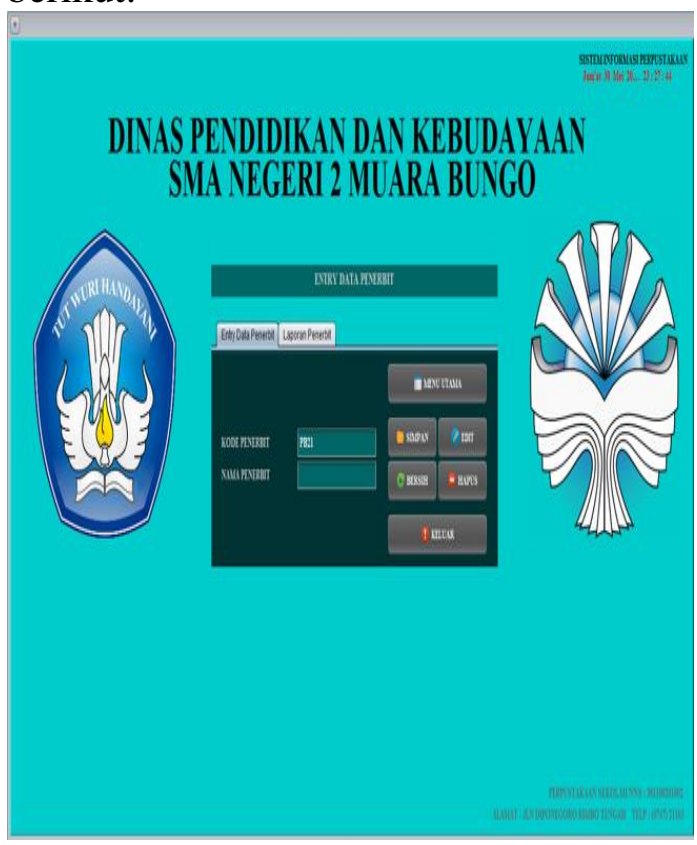

Gambar. 11 Tampilan Input Penerbit

\section{Tampilan Input Pengarang}

Tampilan Input Pengarang berfungsi untuk menginputkan data pengarang. Tampilan program dari Tampilan Input Pengarang dapat dilihat pada gambar 12. berikut:

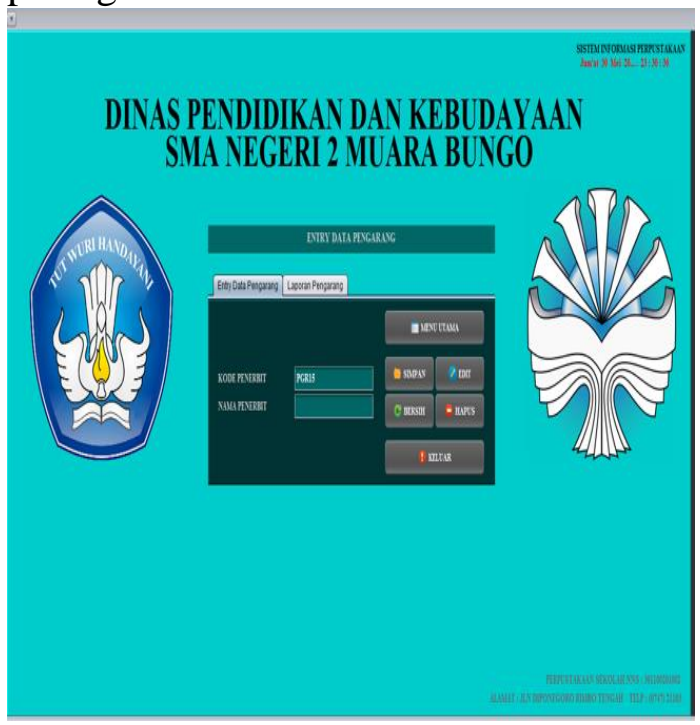

Gambar. 12 Tampilan Input Pengarang

\section{Tampilan Input Buku}

Tampilan Input Buku berfungsi untuk menginputkan data buku. Tampilan program dari Tampilan Input Buku dapat dilihat pada gambar 13. berikut:

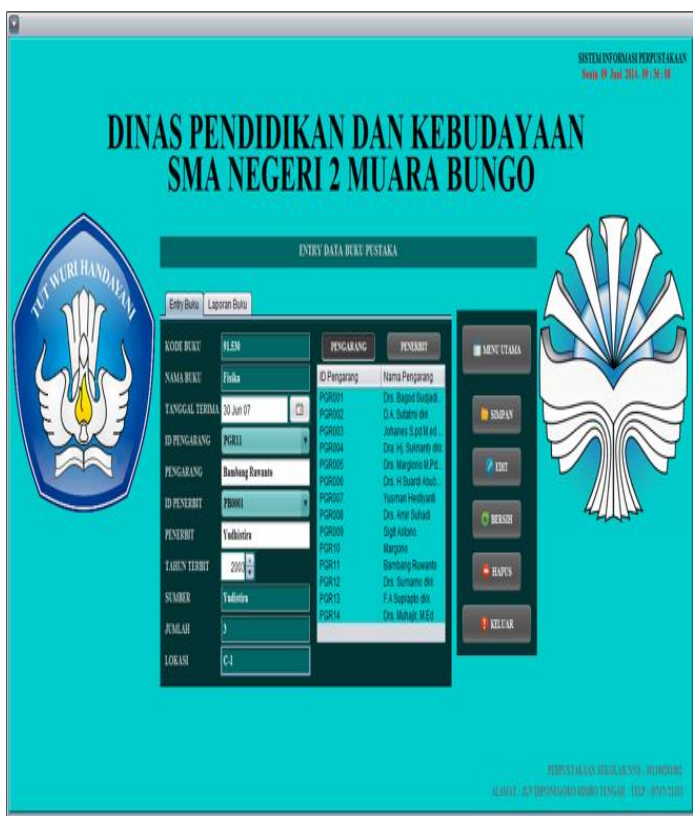

Gambar. 13 Tampilan Input Buku

\section{Tampilan Input Peminjaman Buku}

Tampilan Input Peminjaman Buku berfungsi untuk menginputkan data peminjaman. Tampilan program dari Tampilan Input Peminjaman Bukudapat dilihat pada gambar 14. berikut:

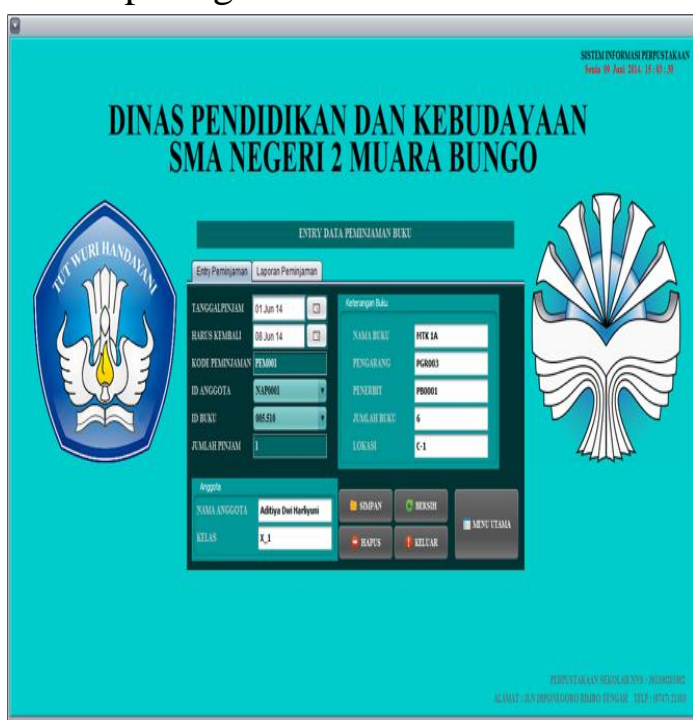

Gambar. 14 Tampilan Input Peminjaman Buku 
Tampilan Input Pengembalian Buku

Tampilan Input Pengembalian Buku berfungsi untuk menginputkan data pengembalian. Tampilan program dari Tampilan Input Pengembalian Buku dapat dilihat pada gambar 15 berikut:

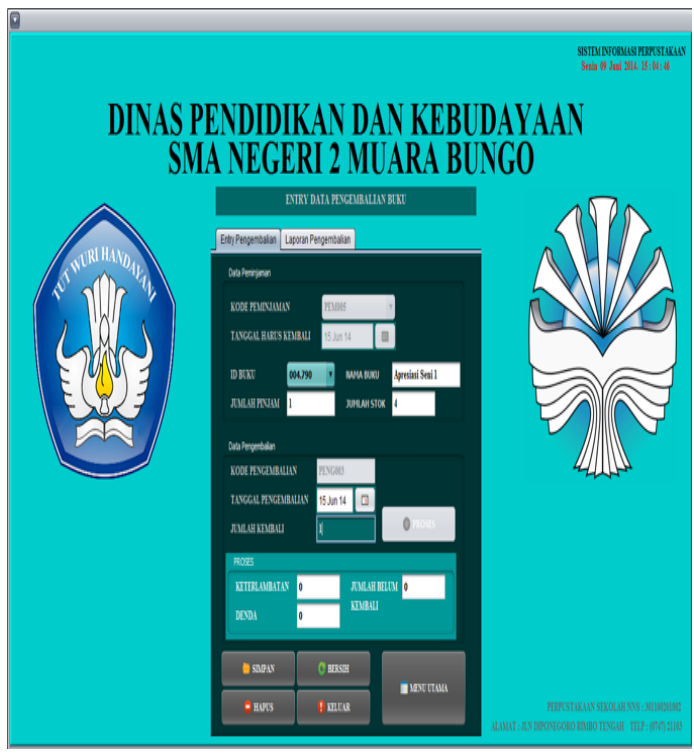

Gambar. 15 Tampilan Input Pengembalian Buku

\section{Tampilan Laporan Anggota}

Tampilan Laporan Anggota berfungsi untuk melaporkan data anggota. Tampilan program dari Tampilan Laporan Anggota dapat dilihat pada gambar 16. berikut:

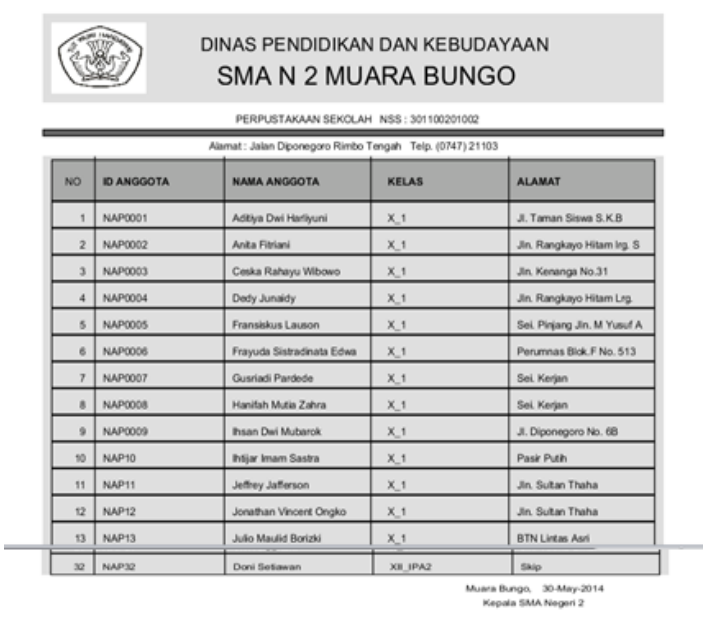

Gambar. 16 Tampilan Laporan Anggota

\section{Tampilan Laporan Penerbit}

Tampilan Laporan Penerbit berfungsi untuk melaporkan data penerbit. Tampilan program dari Tampilan Laporan Penerbit dapat dilihat pada gambar 17 berikut:

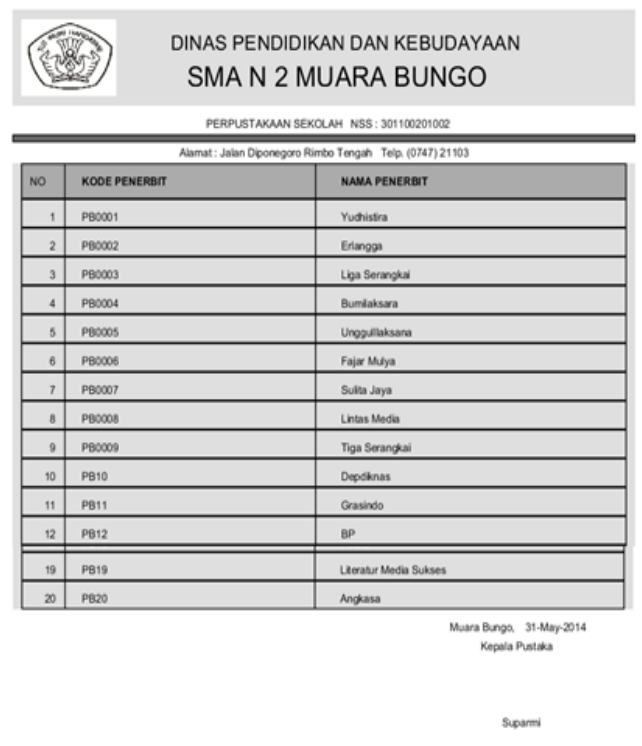

Gambar. 17 Tampilan Laporan Penerbit

\section{Tampilan Laporan Pengarang}

Tampilan Laporan Pengarang berfungsi untuk melaporkan data pengarang. Tampilan program dari Tampilan Laporan Pengarang dapat dilihat pada gambar 18 . berikut:

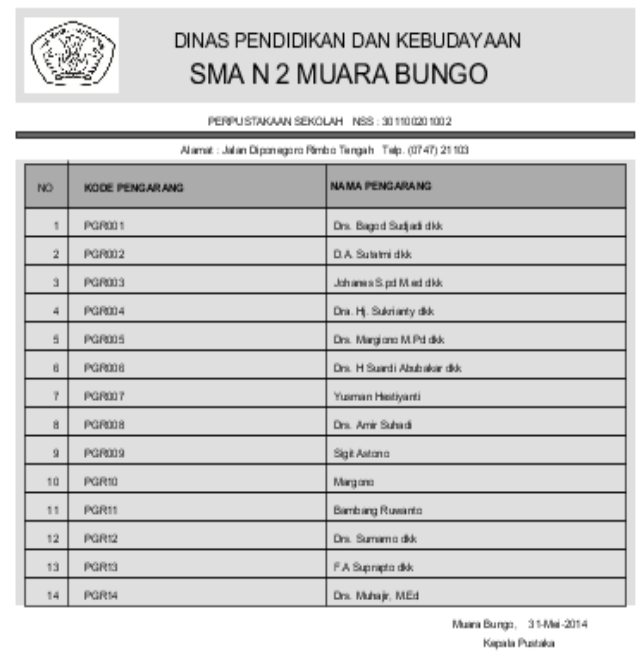

Gambar. 18 Tampilan Laporan Pengarang 


\section{Tampilan Laporan Buku}

Tampilan laporan buku berfungsi untuk melaporkan data buku. Tampilan program dari Tampilan Laporan Buku dapat dilihat pada gambar 19. berikut:

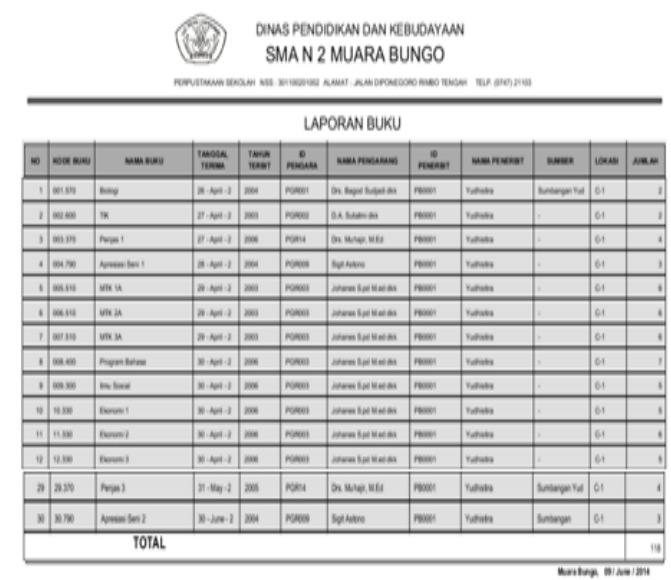

Gambar. 19 Tampilan Laporan Buku

\section{Tampilan Laporan Peminjaman Buku Harian}

Tampilan Laporan Peminjaman Buku Harian berfungsi untuk melaporkan semua data-data hariannya. Tampilan program dari tampilan laporan peminjaman harian dapat dilihat pada gambar 20 berikut:

\section{DNAS PENDDDKAN DAN KEBUDAYAAN}

SMAN2MUARABUNGO

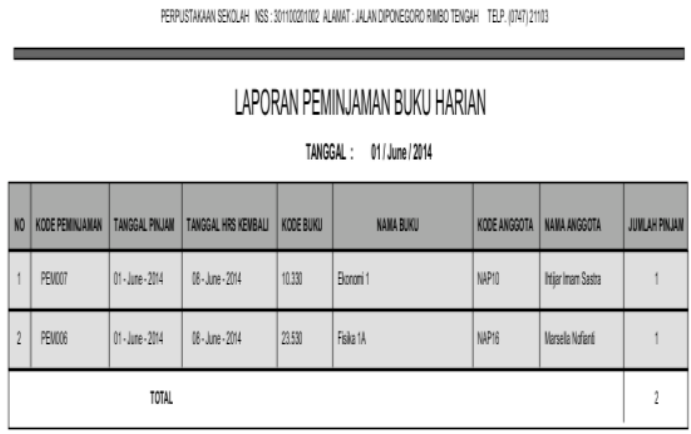

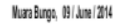

Gambar. 20 Tampilan Laporan Peminjaman Harian
Tampilan Laporan Peminjaman Buku Bulanan

Tampilan laporan peminjaman buku bulanan berfungsi untuk melaporkan semua data-data bulanannya. Tampilan program dari Tampilan Laporan Peminjaman Bulanan dapat dilihat pada gambar 21 . berikut:

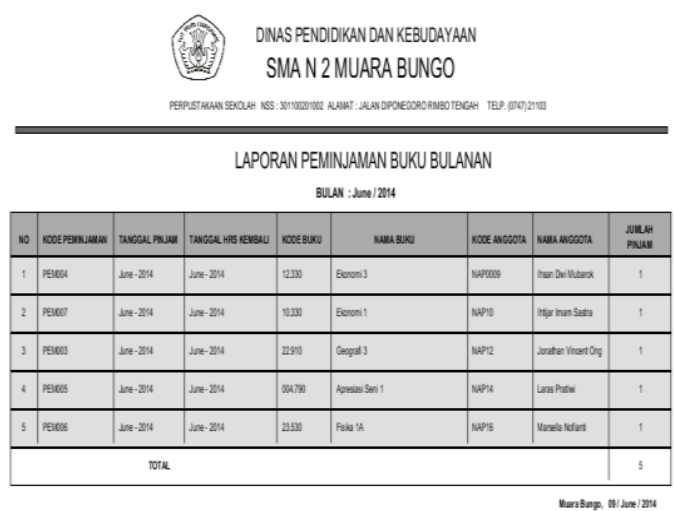

Gambar. 21 Tampilan Laporan Peminjaman Bulanan

\section{Tampilan Laporan Peminjaman Buku Tahunan}

Tampilan Laporan Peminjaman Buku Tahunan berfungsi untuk melaporkan semua data-data tahunannya. Tampilan program dari Tampilan Laporan Peminjaman Tahunan dapat dilihat pada gambar 22 . berikut:

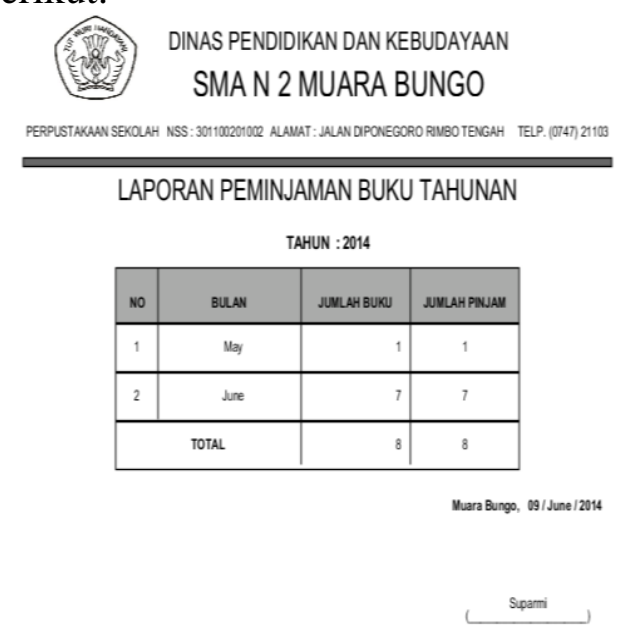

Gambar. 22 Tampilan Laporan Peminjaman Tahunan 


\section{Tampilan Laporan Pengembalian Buku Harian}

Tampilan laporan pengembalian buku harian berfungsi untuk melaporkan semua data-data hariannya. Tampilan program dari Tampilan Laporan Pengembalian Buku Harian dapat dilihat pada gambar 23. berikut:

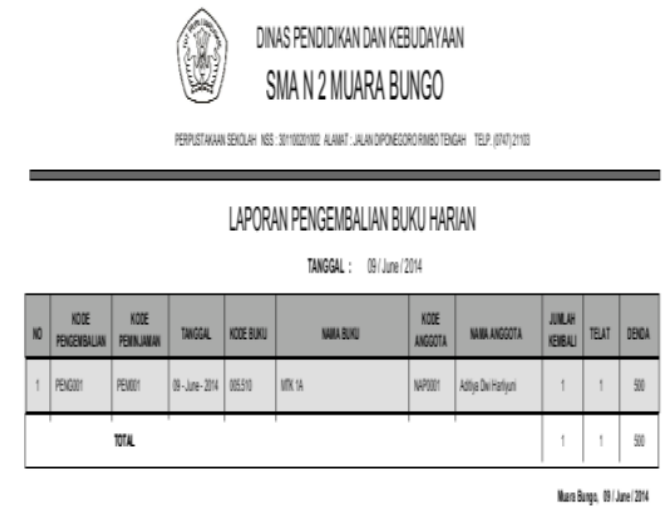

Gambar. 23 Tampilan Laporan Pengembalian Harian

\section{Tampilan Laporan Pengembalian Buku Bulanan}

Tampilan Laporan Pengembalian Buku Bulanan berfungsi untuk melaporkan semua data-data bulanannya. Tampilan program dari Tampilan Laporan Pengembalian Buku Bulanan dapat dilihat pada gambar 24. berikut:

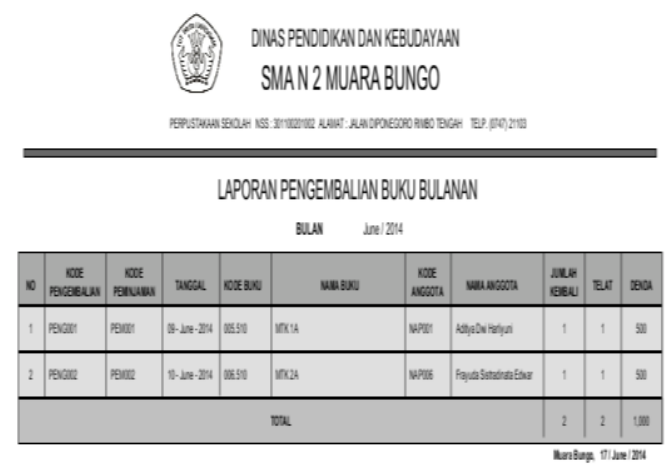

Gambar 24. Tampilan Laporan Pengembalian Bulanan

\section{Tampilan Laporan Pengembalian Buku Tahunan}

Tampilan laporan pengembalian buku tahunan berfungsi untuk melaporkan semua data-data tahunannya. Tampilan program dari tampilan laporan pengembalian buku tahunan dapat dilihat pada gambar 25 . berikut:

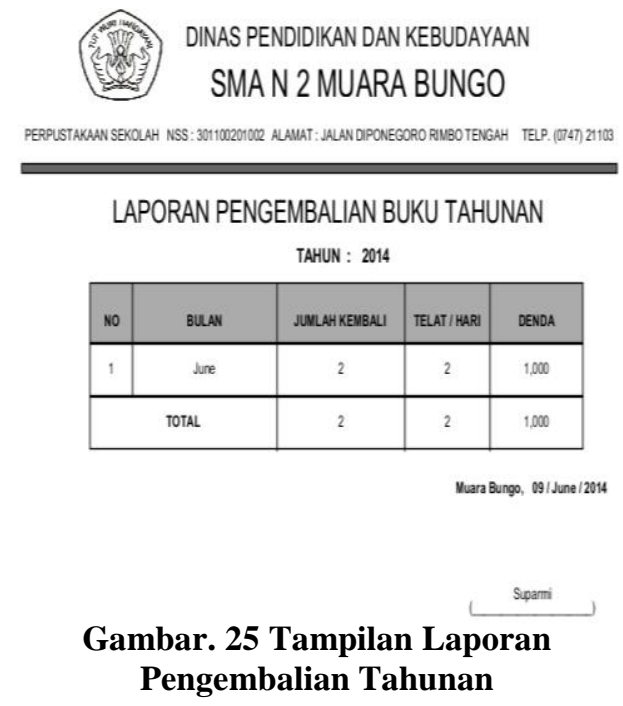

\section{Tampilan Kartu Anggota}

Tampilan Cetak Kartu Anggota berfungsi untuk mendapatkan kartu tanda anggota pustaka. Tampilan program dari Tampilan Cetak Kartu Anggota dapat dilihat pada gambar 26. berikut:

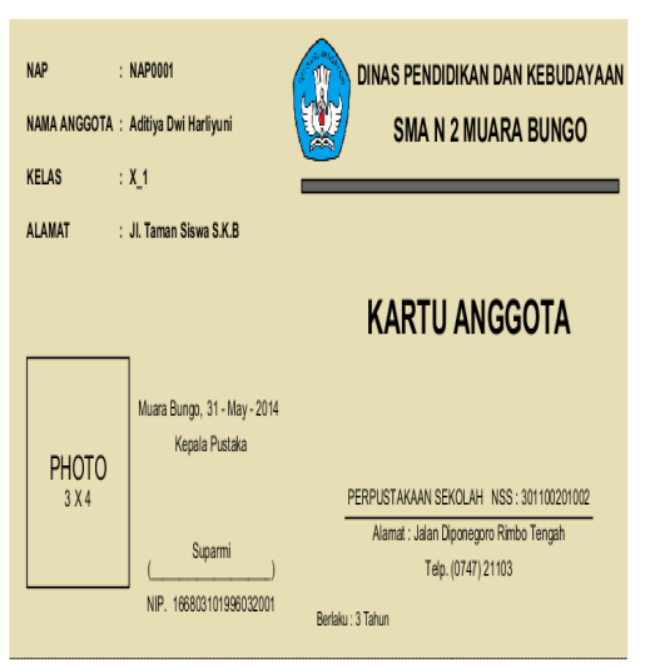

Gambar. 26 Tampilan Kartu Anggota 


\section{Perpustakaan}

Perpustakaan berasal dari kata pustaka yang berarti buku. Setelah mendapat awalan per dan akhiran an menjadi perputakaan, yang berarti kitab, kitab perimbon, atau kumpulan bukubuku yang kemudian disebut koleksi bahan pustaka (Sutarno, 2006).

Dengan kata lain perpustakaan merupakan mata rantai rangkaian sejarah masa lalu, sebagai pijakan masa kini, dan merupakan penuntun dalam merencakan dan mewujudkan masa depan yang lebih baik.

Perpustakaan melaksanakan

fungsi-fungsi antara lain sebagai berikut:

1. Pengkajian kebutuhan pemakai dalam hal informasi dan bahan pustaka.

2. Penyediaan bahan pustaka yang diperkirakan diperlukan, melalui pembelian, langganan, tukar menukar, penggandaan, penerbitan dan lain-lain.

3. Pengolahan dan penyiapan bahan pustaka.

4. Penyimpanan dan pemeliharaan koleksi.

5. Pendayagunaan atau pemberdayaan koleksi.

6. Pemberian layanan kepada masyrakat.

7. Permasyarakatan perpustakaan.

8. Pengkajian dan pengembangan atas semua aspek kepustakawanan.

9. Pemanfaatan koleksi sarana dan prasarana.

10. Pelaksanaan koordinasi dengan berbagai pihak.

11. Keadministrasian perpustakaan.

\section{Pengarsipan}

Koleksi perpustakaan harus diolah dan diatur secara sistematis, dengan tujuan untuk memudahkan penemuan kembali koleksi yang dibutuhkan. Kegiatan pengaturan atau pengelompokan bahan pustaka berdasarkan aturan tertentu disebut dengan klasifikasi.

Tujuan klasifikasi dapat dirinci sebagai berikut :

1. Menghasilkan urusan yang berguna.

2. Penempatan yang tepat bila bahan pustaka diperlukan pemakai, pustaka yang diinginkan mudah diketemukan serta mudah dikembalikan.

3. Penyusunan mekanis

Bahan pustaka baru mudah disisipkan diantara bahan pustaka yang sudah dimiliki. Klasifikasi yang digunakan untuk menayakan subjek berkelas (pengkelasan atau pengelompokan berdasarkan subjek yang dikandung sebuah buku) adalah bagan klasifikasi seperti :

1. Dewey Decimal Classification (DDC) yang dalam istilah indonesia dikenal dengan klasifikasi persepuluh Dewey.

2. Universal Decimal Clasification (UDC).

3. Library of Conggress Classification (LCC).

\section{SIMPULAN}

Berdasarkan pembahasan pada bab sebelumnya maka pada bab terakhir ini penulis dapat mengambil kesimpulan diantaranya:

1. Sistem yang baru dapat meningkatkan kegiatan operasional Pustaka SMA Negeri 2 Muara Bungo, karena informasi yang dihasilkan dapat lebih cepat, akurat, dan penggunaan sistem komputerisasi yang optimal.

2. Keamanan data buku, anggota, peminjaman, dan pengembalian dapat terjamin lebih baik dengan adanya suatu media penyimpanan yaitu database MariaDB yang menyimpan data-data tersebut. 
3. Informasi yang dihasilkan lebih cepat maka dapat membantu dalam pengambilan keputusan secara cepat dan tepat.

4. Kepala Pustaka juga bisa melihat semua hasil laporan yang telah disediakan sehingga dapat dicetak secara langsung.

5. Hasil peminjaman dan pengembalian buku terlihat lebih terstruktur dengan baik dan juga meningkatkan kinerja pada Pustaka SMA Negeri 2 Muara Bungo. 


\section{DAFTAR PUSTAKA}

Firdaus, R., Sakethi, D., \& Rosman, F. (2015). Rancang Bangun Sistem Informasi Perpustakaan Berbasis Web. Journal Komputasi, 3(1), 85-94

Jurnal Komputer. (2014, 27 Maret). Pemograman Java: Pengenalan Java. diakses pada 1 Juli 2018 darihttp://jurnalkomputer.com/atta chments/article/23/PEMROGRA MAN\%20JAVA\%20\%20PENGENALAN.pdf

Novia, J., Napitupulu, H. L., \& Tambunan, M. M. (2013). Perancangan Sistem Pelayanan Informasi Perpustakaan Berbasis Web pada Universitas XYZ. EJournal Teknik Industri FT USU, 1(2), 8-14

Pradani, W., Jamal, A., Triansyah, A. W., \& Utami, A. (2013). Pengembangan Sistem Informasi Perpustakaan Menggunakan Teknologi Google Web Toolkit (GWT). Jurnal Al-Azhar Indonesia Seri Sains dan Teknologi, 2(2), 96-103

Qamaruzzaman, M. H., \& Haris, F. (2016). Aplikasi Mobile Perpustakaan Berbasis Android (Studi Kasus Perpustakaan STMIK Palangkaraya). Jurnal Saintekom, 6(1), 59-70

Rahayu, I. D. (2016). Sistem Informasi Perpustakaan Berbasis Web di Balai Pengkajian dan Pengembangan Komunikasi dan Informatika Surabaya

Sahab, A., \& Pradnya D, W. M. (2015). Perancangan dan Penerapan Sistem Informasi Perpustakaan Sekolah SMAN 5 Kediri. Jurnal Ilmiah DASI, 16(1), 8-11

Sutarno, S. (2006). Perpustakaan dan Masyarakat. Jakarta: Sagung Seto 